\title{
The role of the courts in industrial relations
}

\author{
Sir Ivor Richardson*
}

The topic for discussion today is the role of the courts in industrial relations. I begin by making an immediate qualification and by indicating 2 areas on which $I$ wish to focus. The qualification is that in referring to the courts, I am speaking of the role of the courts of general jurisdiction, particularly the High Court and Court of Appeal, rather than courts and tribunals with specialist responsibilities and notably the Court of Arbitration and its successors, the Industrial Court, the Arbitration Court and now, soon, the Labour Court. The first matter I propose to explore quite briefly concerns the special features of industrial relations which bear on the role of the courts of general jurisdiction in conflict resolution in that field. The second is to say something about the experience of the Court of Appeal in industrial relations questions in recent years.

As we all know, the industrial conciliation and arbitration system pioneered in this country has been of profound social and economic significance. The original legislation enacted in 1894 had as its stated purpose (in terms of the long title) to encourage the formation of industrial unions and associations and facilitate the settlement of industrial disputes by conciliation and arbitration. The same broad goals are reflected in the Labour Relations Act 1987, even if the language used has a more familiar contemporary ring. The stated purposes of that Act (again in terms of the long title) are:

(a) to facilitate the formation of effective and accountable unions and effective and accountable employers organisations

(b) to provide procedures for the orderly conduct of relations between workers and employers

(c) to provide a framework to enable agreements to be reached between workers and employers.

All 3 have an important bearing in considering what if any part the courts of general jurisdiction have to play in industrial relations.

The first is directed to the role of unions and employer organisations as agents of their members. History tells us that in the absence of any organisation there is too great a risk of inequality of bargaining power, of exploitation of workers, and of damage to the social fabric. There are clear social equity considerations and obvious economic implications. As well as economic survival, employment often plays a central part in determining whether individuals are able to achieve many of their aspirations. Equally important for many people, a job is closely linked to feelings of self-worth and dignity. For employers too, and the wider good of society, the labour market should function fairly and efficiently. The presence of effective and accountable unions and employer organisations is the first step to that end.

The second and third stated purposes of the Labour Relations Act are to provide procedures for the orderly conduct of relations between workers and employers and to provide a framework to enable agreements to be reached between workers and employers. The second brings out the crucial point that in the lives of productive enterprises and in the lives of workers alike, the employment of labour needs to be seen as a continuing relationship. As in other human relationships, there will be highs and lows, there will be tensions and hiccups. They 
have to be resolved in a way that will allow that continuing relationship to endure for the common good.

There are 3 reasons why the courts of general jurisdiction are not well fitted for that kind of conflict resolution role. The first is the adversary method of conflict resolution which is the traditional way in which disputes are resolved in the courts of general jurisdiction. By definition it focuses on the dispute itself rather than on a continuing relationship: it pits one side against the other and there is no built-in encouragement to find common ground, let alone a central role for mediation and conciliation. The second is that the field of industrial relations calls for the development of broad expertise and experience. It requires specialised judges who become steeped in the field and who work with those from union and employer ranks who, through their own background and experience, have the confidence of their organisations. Such tribunals are likely to be more sensitive instruments for resolving these disputes. The third and associated reason is that the orderly resolution of industrial conflict in an ongoing relationship is not simply a matter of applying legal principles and attempting to discover on examination who is right and who is wrong. Such questions are often not susceptible to that kind of cold analysis in a forum far removed from the reality of industrial life and industrial strife. Bringing in the law and the regular court processes may simply exacerbate the human drama going on behind an industrial dispute. So it is that for over 90 years our legislation has provided a system of law designed to settle industrial disputes outside the ordinary courts. Even so, there is always scope under the industrial relations legislation to obtain clarification of questions of law arising in the specialised court by way of review or appeal and I shall come back to that shortly when reviewing the experience of the Court of Appeal in the industrial relations field.

It has also always been possible for employers or workers to invoke the common law through the ordinary courts in some circumstances. This is a more controversial area. On the one hand there is the powerful argument that in a society which sets considerable store by the rule of law, no members or sections of the community should be above or beyond the law, and if found to have acted unlawfully they should be answerable through the courts in the ordinary way. If unions or employers can break the law with impunity simply because they are pursuing an industrial goal, will not others in society in other situations claim the same freedom, and where will that leave us? On the other hand there is the counter argument that large employers with their greater economic power are able to shift the industrial balance if they freely invoke the costly and time-consuming processes of litigation through the general courts, and may even destroy effective unionism.

Two recent cases in the Court of Appeal illustrate the problem. The first is New Zealand Baking Trades Employees Industrial Union v General Foods Corporation (NZ) Ltd (1985). After a conciliated agreement was reached, the union sought to engage in second tier bargaining and when unsuccessful began a strike. The company commenced an action against the union and the workers claiming injunctions and an associated inquiry into damages. The High Court granted interim injunctions restraining unions and workers from striking or being party to any strike or instigating, aiding or abetting a strike, or being concerned directly or indirectly in committing acts or omissions in the nature of a strike directed to or in support of a claim for an increase in remuneration during the term of the award.

A disputes committee had earlier held against the union which appealed to the Arbitration Court, and when the appeal from the High Court against a grant of the injunctions was argued in the Court of Appeal, the hearing in the Arbitration Court was about to commence. At that Arbitration Court hearing, that Court was to be asked to determine whether the workers had the right to strike free of sanctions under the Industrial Relations Act 1973. By then, too, the workers were no longer on strike and accordingly the injunctions against them were discharged. Then as to the union, all the judgments recognised the desirability of having industrial law disputes determined in the first instance by the Arbitration Court. However. 4 members of the Court of Appeal upheld the issuing of the injunction against the union for inducing a breach of contract but narrowed the order. In the absence of a clear statutory direction inhibiting the issue of injunctions by the High Court, and having regard to earlier authority recognising their availability, the majority of the judges concluded that the High Court had a role in that field in that case.

I took a different view - namely that in the particular circumstances of that case the dominant consideration was that the underlying industrial relations issues could and should be determined first in the Arbitration Court and the injunction should be discharged. It seemed to me that any intrusion by the High Court into industrial relations, even if there is jurisdiction, must undermine to some extent the legislative policies underlying the Industrial 
Relations Act 1973. I added that such injunctions were rare because judges appreciated that the grant of an interim injunction in industrial matters necessarily shifted the balance of advantage without resolving the underlying issues. That consideration is of course not limited to the industrial relations field. In recent years claims for interim injunctions in all fields have burgeoned. Regrettably they often involve lengthy hearings followed by appeals. Very often the decision on the interim injunction determines the practical outcome. My own view is that courts should be reluctant to issue interim injunctions, especially without notice to the other side, and that if there is urgency there are considerable advantages in trying to fix an early hearing of the substantive claim rather than to have the matter dealt with in that often tactical way.

The new Labour Relations Act reserves to the Labour Court full and exclusive jurisdiction to hear and determine applications for injunctions to stop a strike or lockout, or to prevent a threatened strike or lockout. In short, that area of jurisdiction has been shifted from the High Court to the Labour Court.

The second case is The New Zealand Seamens Industrial Union of Workers $v$ The Nauru Local Government Council (1986). As the result of industrial action a vessel called "Enna G" owned by the Nauru Local Government Council was held in the port of Wellington for 112 days in 1973. Part way through a lengthy hearing in the High Court the Seamens Union admitted liability on one of the causes of action pleaded - that it had induced the Fijian seamen on the "Enna G" to refuse to take the vessel to sea and so to breach their contracts by representing that the union would obtain for them higher wages and better conditions. Damages were assessed at $\$ 63568$ with interest at the rate of 11 percent per year from 23 July 1973 to the date of judgment. eventually entered on 15 December 1982. The union failed in its appeal on various damages and costs questions, but the special point about the case is that the Nauru Local Government Council succeeded on its cross-appeal and the damages were increased by $\$ 142110$, again with interest for $91 / 2$ years. What raised the damages problem was the finding in the High Court that the new shipping service between Auckland and the Islands would have been a financial failure, and the "Enna G" would have been just as costly an investment at sea as it was tied up in port at Wellington. The High Court Judge went on to hold that money which the Nauru Local Government Council would have spent anyway without recoupment from profitable trading was not recoverable as damages, nor could the Council recover general damages for the loss of use of the vessel.

We took a different view. The vessel was to be employed on this run for a mixture of social and economic reasons and with a view to establishing a service hoped to be viable in the long term. The value of the use of an asset is not necessarily confined to the immediate commercial rewards and in our view a plaintiff is not fairly compensated if it receives nothing for being deprived of the use of a vessel beneficial to it. The total award against the Seamens Union including that interest for 9 years to 15 December 1982 was over $\$ 400000$, and the judgment carried further interest from the date of judgment in the High Court (15 December 1982) down to the date of actual payment. So it was very expensive industrial action and no doubt will be seen as demonstrating the risks undertaken by unions or employer organisations in pursuing industrial solutions.

Again the new Act adopts the middle course. It does not exclude all recourse to law - rather it confers exclusive jurisdiction on the Labour Court to hear proceedings founded on 4 recognised areas of tort law in which claims have developed in the industrial relations field. namely conspiracy, intimidation, inducement of breach of contract. and interference by unlawful means with trade, business, or employment (s 242).

I turn now specifically to the second matter I mentioned earlier, the experience of the Court of Appeal in industrial relations cases in recent years. I have gone back 7 years. During that time we have heard 18 cases which have come to the Court on appeal or by way of case stated by the Arbitration Court. In thinking about today's discussion I have reread all the decisions. However, rather than try to go through the cases which would in any event be an unprofitable exercise, I prefer to make a number of general points:

1. Our jurisdiction is largely limited to questions of law and in statistical terms we allowed 6 appeals against the Arbitration Court and dismissed 11 (jurisdiction was declined in one case).

2. As tends to happen in other areas of law too, it is perhaps more in those cases which raise broad questions of legal policy and principle that appellate courts may not be unanimous. Let me give 2 examples. One is New Zealand Drivers' Association v New Zealand Road Carriers (1982). A wage and price freeze had been imposed under the Wage Freeze 
Regulations 1982. Two months later a new regulation, Regulation 5A, was added which prohibited the Arbitration Court during the wage freeze from determining disputes of interest or from continuing with proceedings not already concluded. The Drivers Association challenged the regulation as outside the regulation-making powers conferred by the Governor General in Council by the Economic Stabilisation Act 1948. Section II authorised the making of such regulations as appeared to the Governor General "to be necessary or expedient for the general purposes of this Act or for giving full effect to the provisions of this Act or for the due administration of this Act". The Court split 3:2. The majority upheld Regulation $5 \mathrm{~A}$. It considered it was reasonably capable of being regarded as serving the purpose for which the Act authorised regulations and in particular that the Arbitration Court's work was so central in the economy that without major interference with that work no freeze could have any chance of succeeding. The minority concluded that Regulation 5A had not added anything at all in terms of economic stability since increases in remuneration, a widely defined term, were ruled out under the existing Regulation 5 . The minority also considered that when attention was given to the long history of ready access to the process of arbitration and conciliation as a trusted means of enabling open discussion of wage and employment problems, and so to the promotion of good industrial relations, there were powerful economic as well as social reasons for not shutting down the Arbitration Court in its dispute of interests jurisdiction.

The other example is North Island Wholesale Groceries Ltd v Hewin (1982) where the managing director of the 3 Guys Supermarket chain was held to have been wrongfully dismissed. The method of dismissal was rather unusual. A letter from $\mathrm{Mr}$ Gubay to the managing director recorded that the managing director was not the calibre of man that Gubay wanted in the organisation and instructed the managing director to advertise his own job. The Court had no difficulty in concluding, as had the High Court, that the managing director had been wrongfully dismissed and so was entitled to damages. The problem was over their calculation. He had been contractually entitled to a bonus based on the annual profits. The majority held that the compensation should be determined on the basis of the gross earnings the employee would have received without any adjustment for taxation. In doing so, it departed from the general approach taken by the House of Lords in British Transport Commission v Gourley (1956) for a combination of reasons of policy and principle on the one hand and of tax legislation and the difficulties of ascertaining a fairly quantifiable tax burden fairly attributable to the lost remuneration on the other hand. The minority Judge concluded that the fundamental principle is that damages are compensatory and that to ignore tax would significantly affect the compensatory nature of the award.

Thus in both cases there were basic differences between the approaches of the majority to the legal issue, raising as it did broad questions of legal policy and principle.

3. We take very seriously the direction in (now) s 314 of the new Act and its counterpart in earlier legislation that we have regard to the special jurisdiction and powers of the Labour Court - the section goes on to refer specifically to the provisions of s 279(4) under which the Labour Court determines matters as in equity and good conscience it thinks fit; to s 303(1) under which it may accept, admit, and call for such evidence as in equity and good conscience it thinks fit; to 315 providing for the validation of informal proceedings; and to 317 conferring wide procedural powers enabling the Labour Court "the more effectually to dispose of any matter before it according to the substantial merits and equities of the case". There are frequent references in our judgments to the special expertise of the specialised court and the advantages that that court has over the Court of Appeal in the assessment of industrial relations matters. Thus. Sir Thaddeus McCarthy, speaking for the Court in Winstone Clay Products Limited v Cartledge(Inspector
of Awards) (1984) said:

It is not to be assumed that propositions of law, however prestigious and well established in the High Court or the Court of Appeal, will apply with the same clear force in the Arbitration Court. That is a specialist Court, designed for a specific field. In the matters directed by the statute to come before it, it has exclusive jurisdiction, and, when exercising it, it must take in to account other considerations besides legal issues. It is concerned primarily with fairness. Thus it has been more than once said in this Court that legal technicalities or analogy of rules will not always be helpful in achieving the objects of a Court which has been given what Cooke J characterised as "unusual powers". 
Perhaps of equal significance is the tendency, if we take a different view of the legal point, to refer appeals back to the Arbitration Court for reconsideration by that Court rather than for the Court of Appeal to make its own findings. The other point that has been given some emphasis in our thinking is that the power of the Arbitration Court, now the Labour Court. under s 303(1). to "call for" such evidence as that Court thinks fit, differentiates that Court from other courts by emphasising its supervisory role in the industrial relations field.

4. The cautious approach to industrial relations on the part of the Court of Appeal is reflected in the decision in Quality Pizzas Lid v Canterbury Hotel Employees Union (1983). The High Court had issued a writ of sequestration against the property of the company for disregarding an order of the Arbitration Court to supply the union with a list of names of members of the company's staff covered by the award. Four chartered accountants were appointed as sequestrators of the company which manufactured pizzas and had 3 retail outlets. We rejected the various arguments made against the existence of a jurisdiction in the High Court to ordering sequestration but concluded that a fine was a more appropriate remedy foreshadowing. as we put it, "the cheerless prospect of further money sanctions, perhaps increasing at a specified amount per day while the contempt remains unpurged" (p. 618). The judgment also noted that sequestration which is both drastic and blunt in its operation may have devastating consequences on innocent third parties as it would have had on the employees of Quality Pizzas who would have had to be dismissed if the sequestration had continued in its simple custodial form. We postponed the decision as to the appropriate level of the fine to give the company further time to consider its position. As it happened, following the judgment the company repented, delivered a list of names of employees and was fined.

5. A number of dismissal cases have come on appeal. In Auckland City Council and Hennessy (1982) we held, as had the Arbitration Court, that the word "unjustifiably" could not be confined to matters of legal justification for the actual dismissal: it also applied to the process followed by the employer. So an employer carrying out an inquiry preceding a resignation or dismissal must do so in a fair and reasonable manner.

Then in Marlborough Harbour Board v Goulden (1985) the Court suggested, without deciding, that a similar implication might quite readily be found in private contracts of employment not subject to the 1973 Act. This was for the reason as stated in the judgment: "Fair and reasonable treatment is so generally expected today of any employer that the law may come to recognise it as an ordinary obligation in a contract of service". Principles of natural justice and fairness have an immediate public appeal. The practical difficulty is that as in so many areas the courts could benefit from expert advice as to the social and economic costs and benefits of a change of the kind foreshadowed. but the adversary process is not an ideal vehicle for conducting an extensive social inquiry and there is difficulty in ensuring that the relevant material is actually before the Court and adequately tested.

6. All in all, my impression is that the Court of Appeal has had a distinctly limited influence on the interpretation and application of industrial relations legislation. That may reflect a particularly cautious approach on the part of the Court or, as some might say, an unwillingness to respond to social change in this area. It may suggest that the specialist court arrangements are working particularly well. In any event it seems consonant with the scheme and policy of the legislation that a court functioning as an appellate and review body on matters of law only should have a low, non-activist profile.

\section{List of Cases}

Auckland City Council v Hennessey (1982) ACJ 699, British Transport Commission v Gourley (1956) AC 185.

Marlborough Harbour Board v Goulden (1985) 2 NZLR 378.

New Zealand Baking Trades Employees IUW v General Foods Corporation (NZ) Ltd (1985) 2 NZLR 110.

New Zealand Drivers Association v New Zealand Road Carriers (1982) 1 NZLR 375.

New Zealand Seamens v IUW v The Nauru Local Government Council CA 63/83 judgment 11 July 1986. 
118 Sir Ivor Richardson

North Island Wholesale Groceries Ltd v Hewin (1982) 2 NZLR 176.

Quality Pizzas Ltd v Canterbury Hotel Employees Union (1983) NZLR 612.

Winstone Clay Products Limited v Cartledge (Inspector of Awards) (1984) ACJ 1035. 